\title{
Fire effects on a fire-adapted species: response of grass stage longleaf pine seedlings to experimental burning
}

\author{
Benjamin O. Knapp ${ }^{1 *}$, Lauren S. Pile 2,4 , Joan L. Walker ${ }^{3}$ and G. Geoff Wang ${ }^{2 *}$
}

\begin{abstract}
Background: Longleaf pine (Pinus palustris Mill.) seedlings have a morphological "grass stage" that is considered to be an adaptation to frequent surface fire regimes. However, fire can kill longleaf pine seedlings and thus may play an important role in longleaf pine regeneration dynamics. We used a prescribed burn simulation tool designed to treat individual grass stage longleaf pine seedlings with controlled delivery of fire treatments and then measured survival and growth responses through two growing seasons. Naturally regenerated grass stage longleaf pine seedlings were randomly selected from three size classes and each assigned one of four treatments (Control, no treatment; Clip, mechanical needle removal; $L B$, a low-temperature burn treatment; or $\mathrm{HB}$, a high-temperature burn treatment) in both the dormant season (January) and the growing season (May).

Results: Seedlings greater than $15 \mathrm{~mm}$ root collar diameter had greater than 0.5 probability of survival after the first growing season in the HB treatment, regardless of the season of treatment application, and seedlings across all sizes had greater than 0.6 probability of survival in the LB treatment after the first growing season. The growing season treatment application resulted in additional mortality during the second growing season, across all seedling size classes, which was not observed in the dormant season application. Burning reduced root collar growth through two growing seasons, likely due to needle mortality and the subsequent prioritization of growth to needle production rather than to root or stem growth.

Conclusions: Our results suggest that the interplay between seedling size and fire intensity likely contributes to the success of longleaf pine natural regeneration and that seedling size should be considered when scheduling the first burn following planting of longleaf pine seedlings.
\end{abstract}

Keywords: Fire adaptation, Longleaf pine, Pinus palustris, Prescribed burn simulation tool, Prescribed fire, Southeastern USA, Thermocouple

\footnotetext{
* Correspondence: knappb@missouri.edu; gwang@clemson.edu

${ }^{1}$ School of Natural Resources, University of Missouri, 203-S Anheuser-Busch

Natural Resources Building, Columbia, Missouri 62511, USA

${ }^{2}$ Department of Forestry and Environmental Conservation, Clemson

University, 261 Lehotsky Hall, Clemson, South Carolina 29634, USA

Full list of author information is available at the end of the article
} 


\section{Resumen}

Antecedentes: Las plántulas del pino de hoja larga (Pinus palustris Mill.) tienen un estadio morfológico del tipo "pasto" que es considerado como una adaptación a un régimen frecuente de fuegos de superficie. Sin embargo, el fuego puede matar plántulas de pino de hoja larga, y por lo tanto jugar un rol importante en la dinámica de su regeneración. Usamos una herramienta de simulación de quema prescripta para tratar plántulas individuales de este pino en estado de pasto, mediante la aplicación controlada de un tratamiento de quema, y dos temporadas posttratamiento medimos las respuestas a la supervivencia y el crecimiento. Tres clases de edad de regeneración natural de plántulas de pino de hoja larga en estado de pasto fueron seleccionadas al azar y expuestas cada una a cuatro tratamientos (Control, o no tratado; Cortado, mediante el cual las hojas se removían mecánicamente; Quema a baja temperatura o LB; y Quema a alta temperatura o HB), tanto durante la estación de dormición (enero) como en la de crecimiento (mayo).

Resultados: Las plántulas mayores a $15 \mathrm{~mm}$ de diámetro en la base de la altura del cuello tienen una probabilidad de más del 0,5 de sobrevivir después la primera estación de crecimiento en el tratamiento HB, independientemente de la estación de aplicación del tratamiento, y las plántulas de todos los tamaños tienen un 0,6 o más de probabilidad de sobrevivir en el tratamiento LB después de la primera estación de crecimiento. La estación de aplicación de los tratamientos resultó en una mortalidad adicional durante la estación de crecimiento (mayo) para todas las clases de edad de las plántulas, lo que no fue observado cuando la aplicación fue realizada en la estación de dormición (enero). La quema redujo el crecimiento a la altura del cuello durante las dos estaciones de crecimiento, debido probablemente a la mortalidad de acículas y la subsiguiente priorización del crecimiento de las acículas por sobre la raíz o el tallo.

Conclusiones: Nuestros resultados sugieren que la interrelación entre el tamaño de las plántulas y la intensidad del fuego probablemente contribuya al éxito en la regeneración natural del pino de hoja larga, y que el tamaño de las plántulas debe ser considerado cuando se planea la primera quema posterior a la plantación de plántulas de pino de hoja larga.

\section{Background}

During the past few decades, forest managers have increasingly attempted to incorporate patterns of natural disturbance regimes into forest management practice (Attiwill 1994, Franklin et al. 2002, Palik et al. 2002), with particular interest in understanding the effects of fire regimes on forested ecosystems in both ecological and management contexts. In North America, longleaf pine (Pinus palustris Mill.) ecosystems of the southeastern United States exemplify the tight coupling of ecosystem function and fire regime (Van Lear et al. 2005, Mitchell et al. 2006). Much of the southeastern Coastal Plain region was historically dominated by longleaf pine ecosystems that were maintained with fire return intervals generally $<5$ yr (Frost 2006, Huffman 2006, Stambaugh et al. 2011). In these ecosystems, frequent fire generates a positive feedback among vegetation, fuels, and fire (O'Brien et al. 2008, Mitchell et al. 2009). The combination of long, resinous pine needles shed from the canopy trees and herbaceous ground-layer vegetation creates a fuelbed that ignites easily and burns quickly along the forest floor. Consumption of the forest floor creates space for regenerating individuals of the characteristically species-rich ground flora (Hiers et al. 2007, Veldman et al. 2014) and germination sites for longleaf pine seed (Croker and Boyer 1975, Brockway et al. 2006). Longleaf pines are shade intolerant and poor competitors compared to faster-growing tree species (Boyer 1990). Frequent fires inhibit the development of other woody vegetation (Glitzenstein et al. 1995, Brockway and Lewis 1997, Addington et al. 2015) that would displace longleaf pine regeneration and the herbaceous ground flora. Without fire, longleaf pine ecosystems can quickly transition to alternative states and may be difficult to re-establish without intensive treatments (Martin and Kirkman 2009).

Longleaf pines have a seedling morphology described as a "grass stage," which is also expressed by other pine species that occur within frequent-fire ecosystems across the world (e.g., Pinus merkusii Jungh. \& Vriese ex Vriese, P. montezumae Lamb, P. michoacana Lindl.; Koskela 2000, Keeley 2012). Following germination, grass stage seedlings allocate growth to root and needle production rather to than stem elongation (Brockway et al. 2006, O'Brien et al. 2008). During this stage, the terminal bud is located near the ground surface and is surrounded by a dense tuft of needles that may be consumed by fire but protects the terminal bud from damage (Wahlenberg 1946, O’Brien et al. 2008, Keeley 2012). Although generally considered to be resistant to fire, grass stage longleaf pine seedlings have also been documented to sprout following top-kill, providing an additional mechanism for 
survival with frequent fire (Farrar 1975). For longleaf pine, seedlings emerge from the grass stage and begin stem elongation when the root collar diameter is approximately $25 \mathrm{~mm}$ (Boyer 1990, Ramsey et al. 2003, Knapp et al. 2006), and the thick bark of saplings provides protection from fire during tree recruitment (Schafer et al. 2015).

The grass stage is widely accepted as an adaptation to frequent fire (Brockway et al. 2006, Keeley 2012), yet several studies have reported high mortality rates of small grass stage seedlings following fire (Croker and Boyer 1975, Grace and Platt 1995a, Moule 2013). Brockway et al. (2006) suggested a threshold root collar diameter of $13 \mathrm{~mm}$ for increasing the probability of survival from surface fire, although seedling mortality has also been shown to increase with fire intensity (Jack et al. 2010). Observations of seedling aggregation within canopy openings in naturally regenerated longleaf pine stands may be related to fire-induced mortality of longleaf pine seedlings beneath canopy pines (Grace and Platt 1995a, Avery et al. 2004). However, effects of seedling size and fire intensity on mortality are difficult to separate in observational studies because greater canopy densities often correspond to greater competition (i.e., smaller longleaf pine seedlings) and greater fuel loads from needlefall (i.e., greater fire intensity).

Fire adaptation of longleaf pine seedlings is often associated with traits that allow for survival, whereas the impacts of fire on seedling growth have not been well documented. The consumption of foliage by fire would necessitate the allocation of stored carbohydrate to replace needles and restore pre-burn photosynthetic capacity. Long-term experimental studies have reported growth reductions of longleaf pine saplings following repeated prescribed burning (Boyer 1987). However, the release of nutrients following burning and the consumption of competing vegetation may also provide opportunities for increased growth of survivors (Brockway et al. 2006). Grelen (1978) reported that prescribed burning increased the proportion of seedlings that had emerged from the grass stage in a four-year study in Louisiana, USA. It is not clear to what degree burning alone, in the absence of indirect effects such as changes in resource availability, affects longleaf pine seedling growth responses.

Previous studies have shown season of burn to be an important ecological driver within frequent-fire ecosystems, although effects vary across taxa and by response variable (Platt et al. 1988a, Streng et al. 1993, Hiers et al. 2000). Generally, burning within the growing season has been reported as more effective at killing small hardwood trees than burning in the dormant season (Waldrop et al. 1992, Brose et al. 1999). Seasonal effects of burning on trees and shrubs have been attributed to differences in fire intensity due to differences in weather conditions during burns, as well as to differences in plant physiology at the time of burning (Glitzenstein et al. 1995, Drewa et al. 2002). Although previous studies have reported no effects of season of burn on longleaf pine survival (Glitzenstein et al. 1995, Jack et al. 2010), these studies either considered trees that were out of the grass stage, or grouped grass stage seedlings as a single size class.

This study was designed to examine the direct effects of fire on grass stage longleaf pine seedlings in a controlled field experiment. Whereas previous experimental studies have manipulated fire intensities in longleaf pine ecosystems by removing or adding fuels during burns (e.g., Thaxton and Platt 2006, Jack et al. 2010), we used a prescribed burn simulation tool (PBST) to deliver controlled fire treatments to individual longleaf pine seedlings. We used thermocouple (TC) temperatures as a surrogate of fire intensity. Our specific objectives were to determine: 1) effects of seedling size, fire intensity (measured as TC temperature), and season of treatment application on longleaf pine seedling survival and growth; 2) the contribution of sprouting to longleaf pine seedling survival following burning; and 3) impacts of fire on the initiation of height growth. We hypothesized that: 1) seedling size is positively related to post-fire survival while fire intensity is negatively related to post-fire survival; 2) direct effects of fire on longleaf pine seedlings result in short-term growth reductions; and 3) season of burn would not affect longleaf pine growth or survival, similar to results reported from previous studies.

\section{Methods}

\section{Study sites}

This study was conducted in an approximately 6 ha longleaf pine stand located at Norfolk Southern Corporation's 5830 ha Brosnan Forest property in Dorchester County, South Carolina, USA ( $\left.33^{\circ} 5^{\prime} 9.24 " \mathrm{~N}, 80^{\circ} 15^{\prime} 26.28^{\prime \prime W}\right)$. Soils throughout the stand were somewhat poorly drained Albany sands, a deep Atlantic Coast Flatwoods soil formed from marine or eolian deposits. For the 50-year period prior to study initiation, mean annual temperature at a weather station near the study location $\left(33^{\circ} 2^{\prime} 11.76^{\prime \prime} \mathrm{N}, 80^{\circ}\right.$ $\left.13^{\prime} 57.00^{\prime \prime} \mathrm{W}\right)$ was $16.1{ }^{\circ} \mathrm{C}$, and mean annual precipitation was $125.1 \mathrm{~cm}$. During the growing season (April to August), the mean 50-year precipitation was $65.8 \mathrm{~cm}$, whereas growing season precipitation amounts were $106.3 \mathrm{~cm}$ and $45.0 \mathrm{~cm}$ during 2013 and 2014, respectively. The stand had basal area of $11.7 \mathrm{~m}^{2} \mathrm{ha}^{-1}$ and mean diameter at breast height (DBH) of $41.4 \mathrm{~cm}$ and had not been harvested recently. Prescribed fire is commonly used in longleaf pine forests at Brosnan Forest, and the stand had been previously burned in spring 2011. 


\section{Experimental design}

This study used a completely randomized design with four treatments and a sample population of naturally regenerated, grass stage longleaf pine seedlings. We conducted an inventory of all seedlings within the central 1 ha of the stand and stratified seedlings into three classes of root collar diameter (RCD): Small (6.4 to $13.0 \mathrm{~mm}$ ), Medium (13.1 to $19.0 \mathrm{~mm})$, and Large (19.1 to $25.4 \mathrm{~mm}$ ). Seedlings with obvious damage (e.g., brown-spot needle blight [caused by Mycosphaerella dearnessii Barr]) were removed from consideration for the study, as were seedlings located within $5 \mathrm{~m}$ of canopy trees or within $1 \mathrm{~m}$ of other seedlings. Seedlings in each size class were then randomly assigned to one of four treatments, including an untreated control (Control), a high-temperature burn treatment (HB; maximum [recorded on $1 \mathrm{~s}$ intervals] TC temperature $\sim 425{ }^{\circ} \mathrm{C}$ ), a low-temperature burn treatment (LB; maximum [recorded on $1 \mathrm{~s}$ intervals] TC temperature $\sim 225{ }^{\circ} \mathrm{C}$ ), and mechanical removal of foliage (Clip). Study treatments were applied in January and in May 2013 to compare the effects of dormant and growing season application on response variables. The sample population for the dormant season application was 12 seedlings for each seedling size $\times$ treatment combination $(n=144)$, and the sample population for the growing season application was 10 seedlings per combination $(n=120)$.

Although the PBST may not be able to completely create the conditions of wildland prescribed fire (Kral et al. 2015), the burn treatments used in this study were designed based on data from fires in longleaf pine ecosystems. We considered three primary sources of information for developing the burn treatments. First, we reviewed the published literature for reports of data on fire behavior in longleaf pine ecosystems and found that the reported maximum temperatures derived from measuring devices (e.g., TCs or pyrometers) commonly ranged from $<100$ to $\sim 600{ }^{\circ} \mathrm{C}$ (Gibson et al. 1990, Kennard et al. 2005, Wally et al. 2006, Ellair and Platt 2013), with "cooler" prescribed burns reaching maximum temperatures around $200{ }^{\circ} \mathrm{C}$ (Olson and Platt 1995, Thaxton and Platt 2006) and "hotter" fires reaching maximum temperatures closer to $500^{\circ}$ C (Olson and Platt 1995, Drewa et al. 2002, Hiers et al. 2009, Jack et al. 2010). Because burn conditions and temperature measuring devices affect reported fire temperatures, we also referred to data collected with the same TCs that we used in our study. Our second source of information was a fire temperature dataset collected during experimental prescribed burns between February and April 2008 at Carolina Sandhills National Wildlife Refuge in Chesterfield County, South Carolina, USA. These data describe fire behavior using TCs within fuel types that were dominated by longleaf pine needles, wiregrass (Aristida stricta Michx.), or turkey oak (Quercus laevis Walter) leaf litter (Wenk et al. 2011) and generally indicate that "hotter" burns reached peak temperatures between 400 and $500{ }^{\circ} \mathrm{C}$, and "cooler" burns reached peak temperatures around $200{ }^{\circ} \mathrm{C}$ (Fig. 1). Finally, we conducted a series of small-area $\left(<100 \mathrm{~m}^{2}\right)$ test fires at our study location to describe the time-temperature curves generated by TCs at the time of treatment application, and we found that peak temperatures of the TCs in the test burns were close to $200{ }^{\circ} \mathrm{C}$ but reached temperatures of approximately $400{ }^{\circ} \mathrm{C}$ with addition of pine needle fuels (Fig. 1).

\section{Treatment application}

The HB and LB treatments were applied with a PBST that allowed us to control the time-temperature curves of TCs placed at each seedling's terminal bud (Fig. 2). The PBST was designed as a $21 \mathrm{~cm}$ diameter furnace mounted to a tripod and positioned directly above each target seedling. Two opposite sides of the furnace were each connected to a propane tank with oxygen-acetylene hosing. During treatment application, propane was delivered to the furnace, lit, and then the furnace was lowered onto each target seedling individually. Prior to treatment application, all vegetation and the forest floor were removed in a $1.0 \mathrm{~m}$ radius around each target seedling. We positioned four Type-K thermocouples probes (4.8 $\mathrm{mm}$ thickness), one at each cardinal direction, at least $1 \mathrm{~cm}$ above the soil surface and within $2 \mathrm{~cm}$ of the terminal bud of each seedling. Each burn treatment was applied by slowly lowering the lit furnace onto the target seedling, monitoring temperatures of the TCs using a laptop computer installed with LoggerNet 4.1 software (Campbell Scientific, Inc., Logan, Utah, USA), and raising the furnace to control maximum temperature of the TCs during application. After several calibration burns, we determined that a small amount of pine needle fuel (within a $15 \mathrm{~cm}$ radius of each seedling) at the base of each seedling better simulated the shape of the time -temperature curves of our test fires (Fig. 1). The Clip treatment was applied by removing all foliage to within $2.5 \mathrm{~cm}$ of the fascicle sheath with garden pruners. The dormant-season treatment was applied 9-14 January 2013 , and the growing season treatment was applied 2024 May 2013.

\section{Data collection}

We recorded RCD $(\mathrm{mm})$ and height from the root collar to the top of the terminal bud $(\mathrm{cm})$ of each seedling prior to treatment. For each treatment burn, we recorded the ambient air temperature $\left({ }^{\circ} \mathrm{C}\right)$, relative humidity (\%), and wind speed $\left(\mathrm{m} \mathrm{s}^{-1}\right)$ using a Kestrel 3000 portable weather station (Nielsen-Kellerman Co., Boothwyn, Pennsylvannia, USA). During the burns, TC temperatures $\left({ }^{\circ} \mathrm{C}\right)$ were recorded every second. In August 2013 and 2014, we surveyed seedling survival 

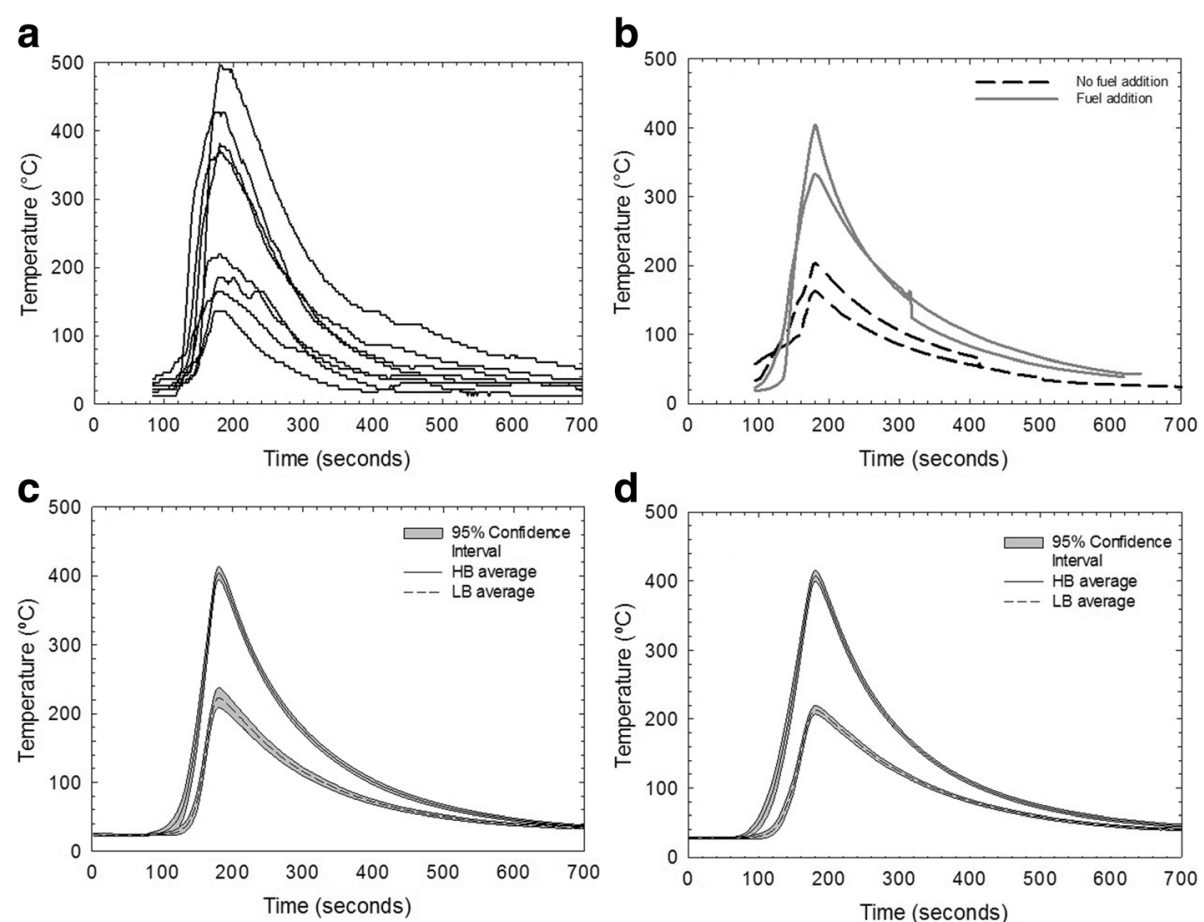

Fig. 1 Time-temperature curves for (a) prescribed burns from Carolina Sandhills National Wildlife Refuge (February - April 2008) used as reference for treatment development; (b) test fires with and without fuel additions conducted at our study site (January 2013); and mean and 95\% confidence intervals for (c) the January ( $n=36$ seedlings per treatment) and (d) the May $(n=30$ seedlings per treatment) treatment applications. All curves were created by aligning the maximum temperature for each time-temperature curve with $180 \mathrm{~s}$ to standardize display

and recorded the RCD and height of every seedling. Thus, seedling data were collected prior to treatment application and 8 and 20 months following treatment for the January application, and 4 and 16 months following treatment for the May application. In August 2014, each seedling was carefully excavated from the soil to preserve as much of the root system as possible and returned to the laboratory to determine biomass. Each seedling was separated into needles, stem, and roots, and each section was oven-dried at $80{ }^{\circ} \mathrm{C}$ to a constant mass and weighed to determine biomass (g).

\section{Data analyses}

We tested the assumption that the PBST allowed repeatable, controlled treatment application to each seedling by using Analysis of Variance (ANOVA) to test for effects of the month of burn application (January or May), the burn treatment (HB or LB), seedling size (Small, Medium, or Large), and all possible interactions on response variables related to the burning environment. We tested for differences among these variables as indication of consistent conditions during treatment application. Response variables included ambient air temperature, relative humidity, and wind speed at the time of treatment, as well as maximum TC temperature $\left({ }^{\circ} \mathrm{C}\right.$; Max), the area under the $\mathrm{TC}$ temperature curve above a threshold of $60{ }^{\circ} \mathrm{C}$ (Area60), and the duration (number of seconds) TC temperature remained above a threshold of $60{ }^{\circ} \mathrm{C}$ (Dur60). The threshold of $60{ }^{\circ} \mathrm{C}$ is the temperature at which cellular necrosis occurs (Stephan et al. 2010), and previous fire effects studies commonly include area under the temperature curve and duration as important variables to describe fire effects (Kennard et al. 2005, Wally et al. 2006).

We classified each seedling from the initial seedling population as alive or dead in August 2013 and August 2014. We used contingency tables with the MantelHaenszel chi-square test to determine treatment effects on survival for each size class and month of burn application. Similarly, we tested for effects of month of application on survival for each treatment and each seedling size class. For significant treatment effects, pair-wise comparisons were made using chi-square tests on each pair of treatments, and $P$-values were adjusted using the Bonferroni adjustment.

We used logistic regression to model the probability of seedling survival in August 2013 (after one growing season) and in August 2014 (after two growing seasons). We modeled survival probability of all seedlings based on treatment (Control, Clip, HB, LB), initial (pre treatment) $\mathrm{RCD}$, and application month. In the absence of a significant effect of application month, data were combined 

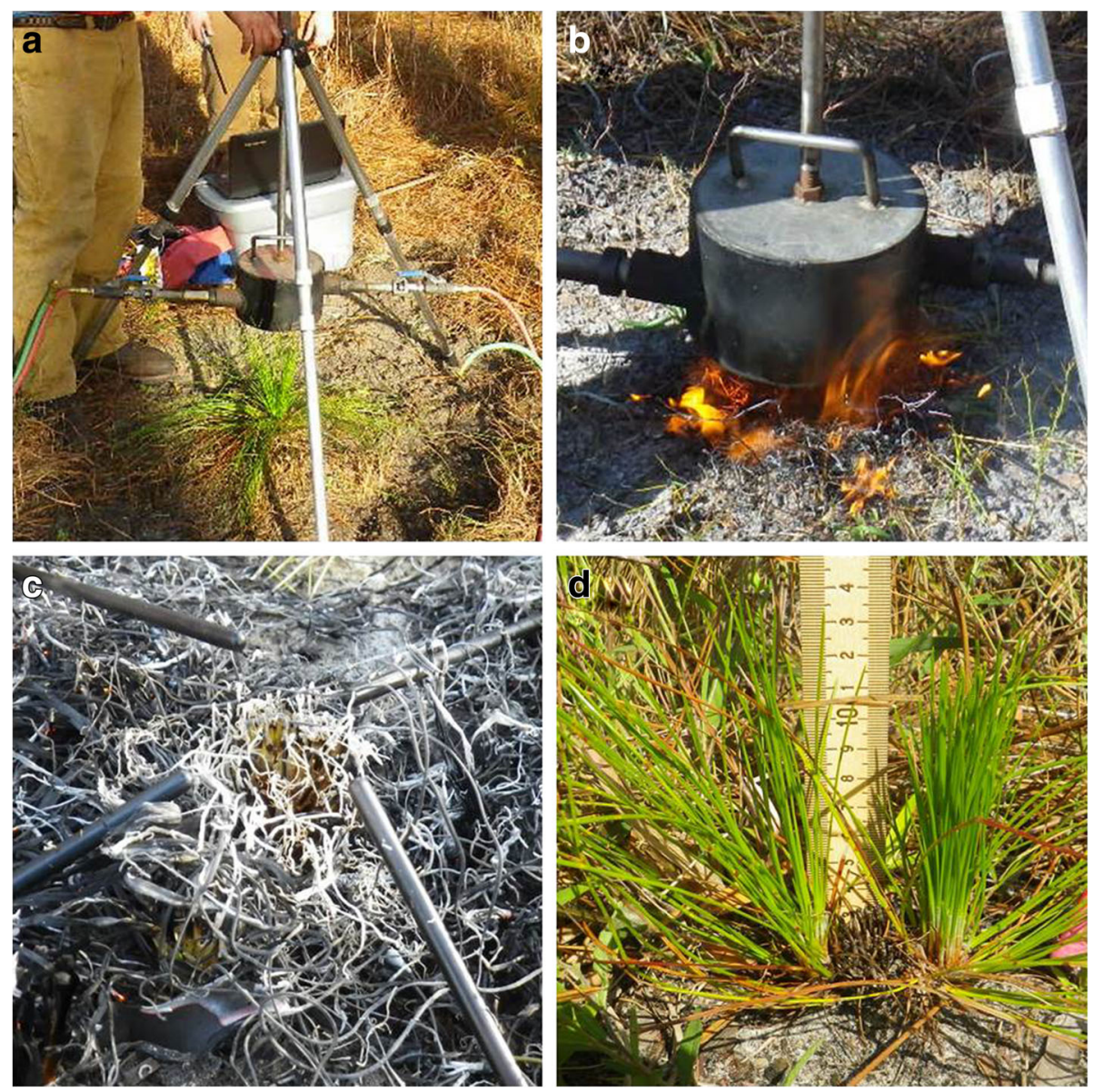

Fig. 2 Photographs of (a) the prescribed burn simulation tool, (b) a burn treatment being applied to a longleaf pine seedling in 2013, (c) a seedling and thermocouples immediately post burn (HB treatment), and (d) seedling recovered by sprouting in South Carolina, USA, in August 2014

across months. We also used an information-theoretic approach to determine the best model for predicting survival of burned seedlings (i.e., only HB and LB seedlings) based on initial RCD, season of application, and three different fire variables (Max, Area60, Dur60). Candidate models included a null (intercept only); four models with intercept plus one variable (initial RCD, Max, Area60, or Dur60); four models of intercept, initial RCD, plus one variable (application season, Max, Area60, or Dur60); thee models of intercept, application month, plus one variable (Max, Area60, or Dur60); and three models of intercept, initial RCD, application season, plus one variable (Max, Area60, or Dur60). We used Akaike Information Criterion $\left(\mathrm{AIC}_{\mathrm{c}}\right)$ for small sample size to calculate $\Delta \mathrm{AIC}_{\mathrm{c}}$ and Akaike weights $\left(w_{\mathrm{i}}\right)$ for each model. Lower $\mathrm{AIC}_{\mathrm{c}}$ scores and greater $w_{\mathrm{i}}$ values indicated better models for the data (Burnham and Anderson 2003). In the case of significant initial RCD, results are presented by seedling size class (Small, Medium, Large).
To quantify growth, we first calculated the root collar area $\left(\mathrm{RCA} ; \mathrm{mm}^{2}\right)$ for the initial measurement period (at the time of treatment application) and for the August 2014 measurement period. We then calculated the RCA increment as the difference between root collar area in August 2014 and the initial RCA for each seedling. We used ANOVA to test for effects of study treatment, seedling size class, and the interaction of treatment and size class on RCA increment and on root biomass, stem biomass, needle biomass, and total biomass of seedlings destructively sampled in August 2014. In the case of significant effects, we used Tukey's Honestly Significant Difference adjustment to test for differences in pair-wise comparisons. Analyses for RCA increment and biomass were conducted separately for each month of treatment application because the seedling populations in each application month experienced different growing period lengths during the study duration. We used $\alpha=0.05$ to determine statistical significance for all analyses. 


\section{Results}

\section{Application of burn treatment}

Air temperature, relative humidity, and wind speed did not differ between burn treatments or among seedling size classes (Table 1). Air temperature and relative humidity were greater in May than in January, and wind speed was greater in January than in May. Time -temperature curves indicated similar maximum temperatures for each month of application, with low variability within each treatment level (Fig. 1). As intended, Max was significantly different between treatment levels but did not differ by month of burn application or seedling size class (Table 2). Mean Area60 and Dur60 were each greater in the May burn application than in the January application and were each greater for Large seedlings than for Small seedlings.

\section{Survival}

For Control and Clip treatments, there were no differences in survival between the January and the May applications (Fig. 3). Survival in August 2014 was high for Controls $(\geq 90 \%)$ for all seedling sizes and both months of burn application. The LB treatment had lower survival than Control $\left(X^{2}=8.14, P=0.004\right)$ and Clip $\left(X^{2}=\right.$ $8.14, P=0.004$ ) for only Small seedlings treated in May. Small seedlings treated with $\mathrm{HB}$ had significantly lower survival than all other treatments in the January application (Control $X^{2}=19.46, P<0.001$; Clip $X^{2}=15.97, P<$ 0.001 ; LB $\left.X^{2}=13.03, P<0.001\right)$ and significantly lower survival than Control $\left(\chi^{2}=8.14, P=0.004\right)$ and Clip $\left(\chi^{2}\right.$ $=8.14, P=0.004)$ treatments in the May application. The Medium seedlings treated with HB in May had significantly lower survival than all other treatments (Control $X^{2}=7.13, P=0.008 ;$ Clip $X^{2}=4.80, P=0.029$; LB $X^{2}=$ 7.13, $P=0.008$ ). Survival differences between months of
Table 2 Heat delivery during burn treatment application by month, treatment, and longleaf pine seedling size class in South Carolina, USA, in 2013. There were no significant interactions among any of the independent variables in the model; the same superscript letter within a column and effect indicates no significant difference; $\mathrm{HB}$ = high-intensity burn; LB = low-intensity burn treatment; Max = peak temperature during burn application; Area60 $=$ area above $60^{\circ} \mathrm{C}$ within the time-temperature curve; Dur60 $=$ duration (s) with temperature above $60^{\circ} \mathrm{C}$

\begin{tabular}{|c|c|c|c|c|c|c|c|}
\hline \multirow[b]{2}{*}{ Effect } & \multirow[b]{2}{*}{ Level } & \multicolumn{2}{|c|}{$\operatorname{Max}\left({ }^{\circ} \mathrm{C}\right)$} & \multicolumn{2}{|l|}{ Area60 } & \multicolumn{2}{|c|}{ Dur60 (s) } \\
\hline & & Mean & SE & Mean & SE & Mean & SE \\
\hline \multirow[t]{3}{*}{ Month } & January & 315 & 11 & $52951^{b}$ & 2001 & $348^{b}$ & 7 \\
\hline & May & 310 & 12 & $60276^{a}$ & 2428 & $408^{\mathrm{a}}$ & 9 \\
\hline & $P$-value & 0.364 & & $<0.001$ & & $<0.001$ & \\
\hline \multirow[t]{3}{*}{ Treatment } & $\mathrm{HB}$ & $405^{a}$ & 2 & $72183^{a}$ & 1207 & $423^{a}$ & 7 \\
\hline & LB & $220^{b}$ & 3 & $40378^{b}$ & 897 & $327^{b}$ & 6 \\
\hline & $P$-value & $<0.001$ & & $<0.001$ & & $<0.001$ & \\
\hline \multirow[t]{4}{*}{ Size class } & Large & 306 & 16 & $58961^{a}$ & 3069 & $394^{a}$ & 11 \\
\hline & Medium & 314 & 14 & $55191^{\mathrm{ab}}$ & 2641 & $369^{b}$ & 12 \\
\hline & Small & 317 & 14 & $54689^{b}$ & 2475 & $363^{b}$ & 9 \\
\hline & $P$-value & 0.144 & & 0.016 & & 0.002 & \\
\hline
\end{tabular}

application were found in two cases: Medium seedlings in the $\mathrm{HB}$ treatment $\left(\chi^{2}=4.25, P=0.039\right)$ and Small seedlings in the LB treatment $\left(X^{2}=4.23, P=0.040\right)$, with January treatment survival exceeding May treatment survival in both cases.

There was no effect of application month on the probability of survival after one growing season $\left(F_{1,255}=\right.$ $0.93, P=0.335$ ), with the probability of survival positively related to initial seedling size for $\mathrm{LB}$ and $\mathrm{HB}$ treatments but not for Clip or Control (Fig. 4a). The probability of survival after two growing seasons was significantly

Table 1 Weather conditions during burn treatment application by month, treatment, and longleaf pine seedling size class in South Carolina, USA, in 2013. There were no significant interactions among any of the independent variables in the model; the same superscript letter within a column and effect indicates no significant difference; HB = high-intensity burn; LB = low-intensity burn treatment

\begin{tabular}{|c|c|c|c|c|c|c|c|}
\hline \multirow[b]{2}{*}{ Effect } & \multirow[b]{2}{*}{ Level } & \multicolumn{2}{|c|}{ Air temperature $\left({ }^{\circ} \mathrm{C}\right)$} & \multicolumn{2}{|c|}{ Relative humidity (\%) } & \multicolumn{2}{|c|}{ Wind speed $\left(\mathrm{m} \mathrm{s}^{-1}\right)$} \\
\hline & & Mean & SE & Mean & SE & Mean & SE \\
\hline \multirow[t]{3}{*}{ Month } & January & $26.0^{\mathrm{b}}$ & 0.2 & $61.0^{\mathrm{b}}$ & 1.0 & $2.8^{\mathrm{a}}$ & 0.4 \\
\hline & May & $28.9^{\mathrm{a}}$ & 0.6 & $67.9^{\mathrm{a}}$ & 1.3 & $1.6^{\mathrm{b}}$ & 0.1 \\
\hline & $P$-value & $<0.001$ & & $<0.001$ & & $<0.001$ & \\
\hline \multirow[t]{3}{*}{ Treatment } & $\mathrm{HB}$ & 27.8 & 0.5 & 63.3 & 1.1 & 2.2 & 0.4 \\
\hline & LB & 26.9 & 0.4 & 64.9 & 1.3 & 2.3 & 0.3 \\
\hline & $P$-value & 0.074 & & 0.290 & & 0.793 & \\
\hline \multirow[t]{4}{*}{ Size class } & Large & 28.1 & 0.6 & 64.8 & 1.2 & 2.0 & 0.2 \\
\hline & Medium & 27.5 & 0.6 & 64.0 & 1.5 & 2.3 & 0.5 \\
\hline & Small & 26.6 & 0.4 & 63.6 & 1.7 & 2.4 & 0.5 \\
\hline & $P$-value & 0.089 & & 0.820 & & 0.144 & \\
\hline
\end{tabular}



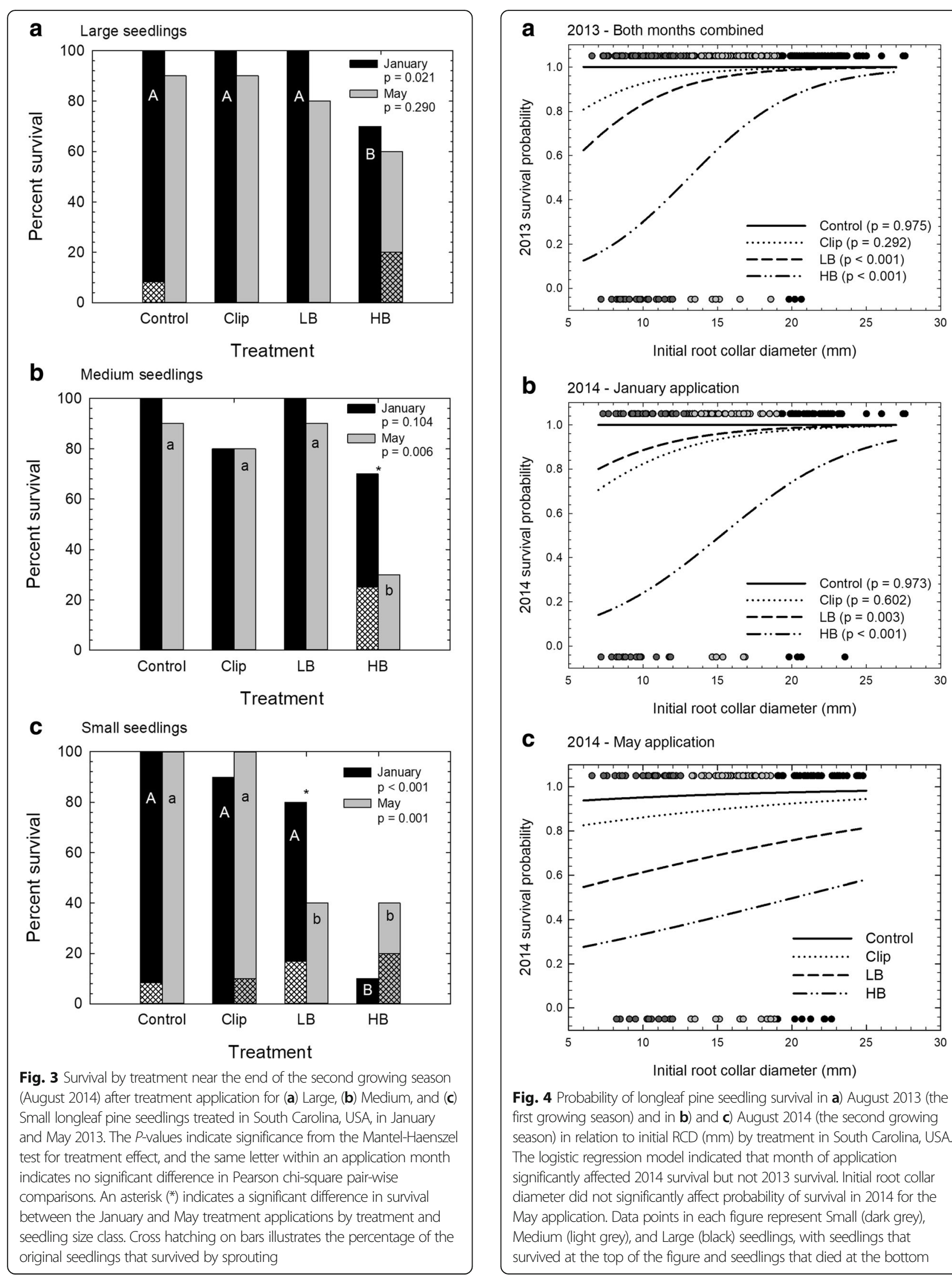

b 2014 - January application

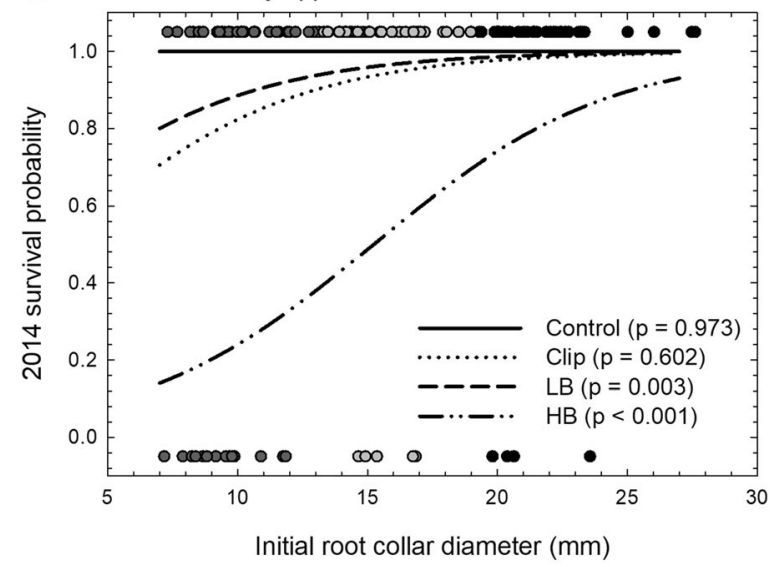

C 2014 - May application

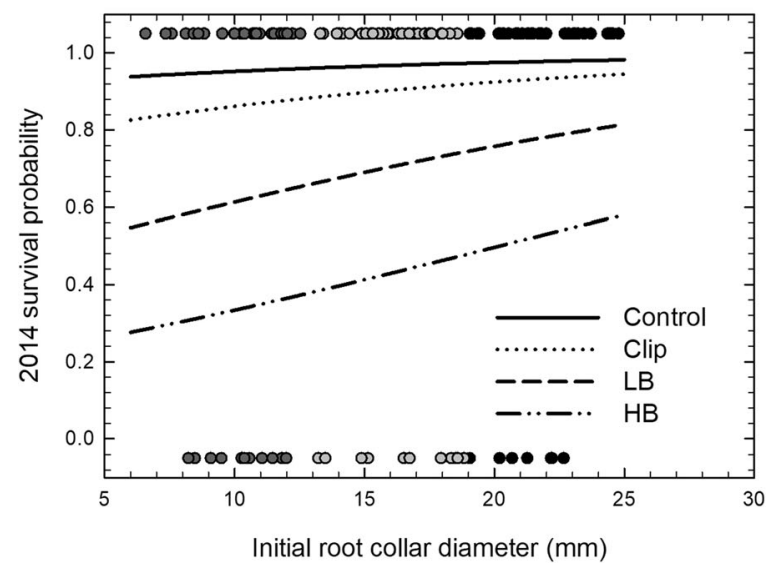

Fig. 4 Probability of longleaf pine seedling survival in a) August 2013 (the first growing season) and in b) and c) August 2014 (the second growing season) in relation to initial RCD $(\mathrm{mm})$ by treatment in South Carolina, USA. The logistic regression model indicated that month of application significantly affected 2014 sunvival but not 2013 survival. Initial root collar diameter did not significantly affect probability of survival in 2014 for the May application. Data points in each figure represent Small (dark grey), Medium (light grey), and Large (black) seedlings, with seedlings that survived at the top of the figure and seedlings that died at the bottom 
affected by month of application $\left(F_{1,257}=5.33, P=\right.$ 0.022). Seedlings treated in January had survival models that appeared similar to those from the first growing season, with the probability of survival positively related to initial seedling size for LB and HB (Fig. 4b). For seedlings treated in May, initial seedling RCD was not significantly related to the probability of survival after two growing seasons $\left(F_{1,114}=1.93, P=0.168\right.$; Fig. $\left.4 c\right)$, although survival was significantly lower for HB than for Control based on non-overlapping 95\% confidence intervals of parameter estimates. Among the burned seedlings, the best model of the probability of first-year survival included initial RCD and Area60, whereas the best model of the probability of survival after two growing seasons included initial RCD, application month, and Max (Table 3, Fig. 5).

By the end of the study period, a portion of the seedling population had survived by sprouting in all treatments, including two seedlings in the Control treatment groups (Fig. 3). In the Medium and Large size classes, treated seedlings in only the HB treatment had sprouted. Sprouting contributed to survival of half the Small seedlings remaining at the end of the study from the May application of the HB treatment.

Table 3 Akaike Information Criterion values for each candidate model for the probability of seedling survival in 2013 and in 2014 following burn treatments applied to longleaf pine seedlings in South Carolina, USA, in 2013. Lower AIC $C_{c}$ values and higher $w_{i}$ values indicate better models for the data, and the best model for each year is shown in boldface; RCD = root collar diameter, Max = peak temperature during burn application; Area60 $=$ area above $60^{\circ} \mathrm{C}$ within the time-temperature curve; Dur60 = duration (s) with temperature above $60{ }^{\circ} \mathrm{C}$; Month $=$ month of treatment application (January or May)

\begin{tabular}{lcccccc}
\hline & \multicolumn{3}{c}{2013 survival } & \multicolumn{3}{c}{2014 survival } \\
Model & $\mathrm{AIC}_{c}$ & $\Delta \mathrm{AIC}_{c}$ & $w_{i}$ & $\mathrm{AlC}_{c}$ & $\Delta \mathrm{AIC}_{c}$ & $w_{i}$ \\
Null (intercept only) & 143.01 & 49.63 & 0.00 & 172.71 & 36.18 & 0.00 \\
Initial RCD & 118.70 & 25.33 & 0.00 & 163.25 & 26.73 & 0.00 \\
Max & 123.84 & 30.47 & 0.00 & 150.89 & 14.36 & 0.00 \\
Area60 & 132.10 & 38.73 & 0.00 & 155.43 & 18.90 & 0.00 \\
Dur60 & 139.65 & 46.28 & 0.00 & 162.36 & 25.83 & 0.00 \\
Initial RCD; Month & 120.07 & 26.70 & 0.00 & 160.65 & 24.12 & 0.00 \\
Initial RCD; Max & 94.58 & 1.21 & 0.25 & 140.54 & 4.01 & 0.07 \\
Initial RCD; Area60 & $\mathbf{9 3 . 3 7}$ & $\mathbf{0 . 0 0}$ & $\mathbf{0 . 4 5}$ & 138.27 & 1.74 & 0.22 \\
Initial RCD; Dur60 & 103.44 & 10.07 & 0.00 & 143.22 & 6.69 & 0.02 \\
Month; Max & 134.14 & 40.77 & 0.00 & 148.35 & 11.83 & 0.00 \\
Month; Area60 & 134.14 & 40.77 & 0.00 & 156.31 & 19.79 & 0.00 \\
Month; Dur60 & 141.53 & 48.16 & 0.00 & 164.20 & 27.67 & 0.00 \\
Initial RCD; Month; Max & 95.71 & 2.33 & 0.14 & $\mathbf{1 3 6 . 5 3}$ & $\mathbf{0 . 0 0}$ & $\mathbf{0 . 5 1}$ \\
Initial RCD; Month; Area60 & 95.43 & 2.06 & 0.16 & 138.69 & 2.16 & 0.17 \\
Initial RCD; Month; Dur60 & 104.64 & 11.27 & 0.00 & 145.22 & 8.69 & 0.01 \\
\hline
\end{tabular}

\section{a 2013 - Both months combined}

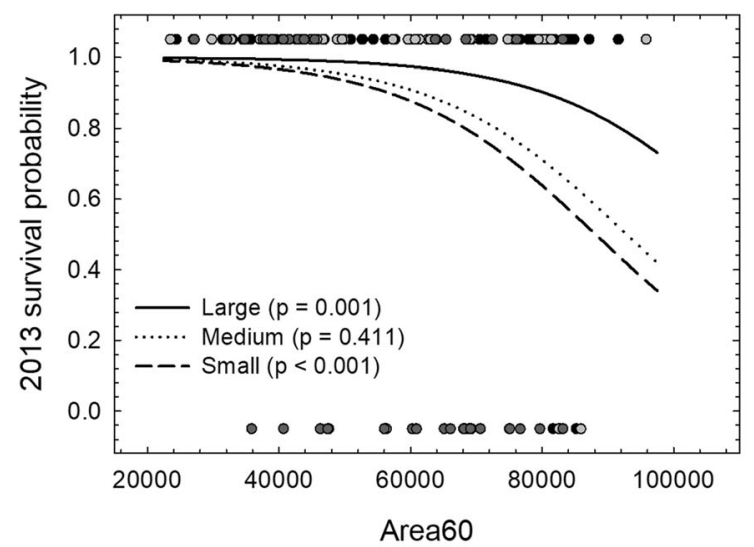

b 2014 - January application

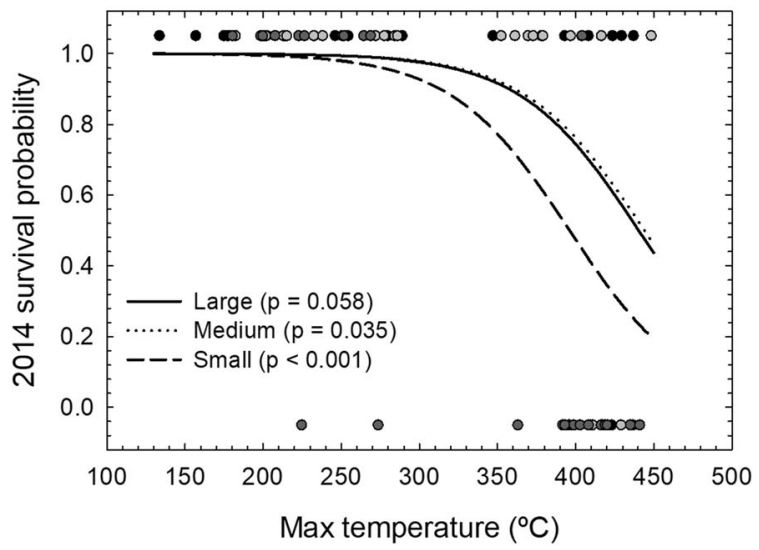

C 2014 - May application

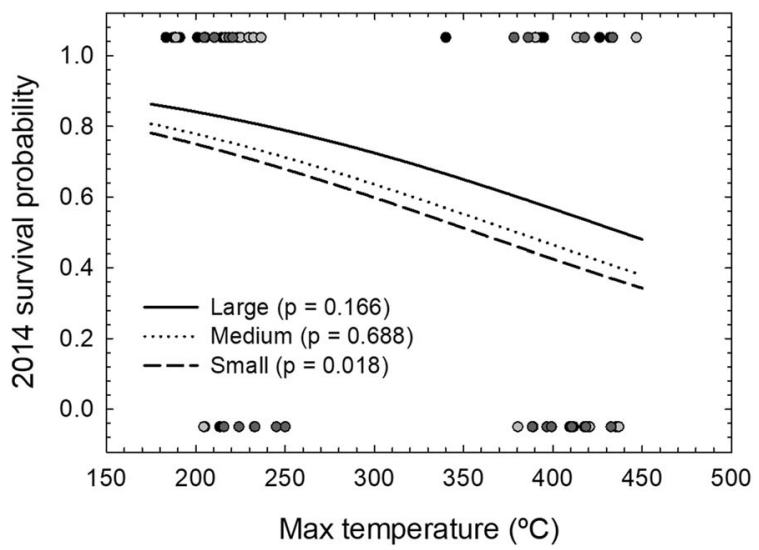

Fig. 5 Probability of longleaf pine seedling survival in (a) August 2013 in relation to Area60 for both application months combined, and probability of seedling survival in August 2014 in relation to Max temperature for (b) the January application and (c) the May application from logistic regression by size class. Data points in each figure represent Small (dark grey), Medium (light grey) and Large (black) seedlings, with seedlings that survived at the top of the figure and seedlings that died at the bottom 


\section{Growth and biomass}

There was no significant interaction between treatment and seedling size class for RCA increment for either application month (January $F_{6}, 109=0.97, P=0.451$; May $\left.F_{6,77}=1.12, P=0.360\right)$. Treatment did not significantly affect the RCA increment for the May application but was significant for the January application (Fig. 6a). Seedlings in the Control treatment grew an average of $104 \mathrm{~mm}^{2}$ from January 2013 through August 2014, which was significantly greater than seedlings from any other treatment (Clip $F_{1,109}=27.14, P<0.001 ; \mathrm{LB} F_{1}$, $109=10.69, P=0.001 ;$ HB $F_{1}, 109=7.08, P=0.044$; Fig. 6a). Mean RCA increment of seedlings from the Clip, $\mathrm{LB}$, and HB were not different from each other. Seedling size class did not significantly affect RCA increment for the May application but was significant for the January application (Fig. 6b).

There were no significant interaction effects between seedling size and treatment on total $\left(F_{6}, 105=1.33, P=\right.$ $0.250)$, $\operatorname{root}\left(F_{6,105}=1.48, P=0.194\right)$, stem $\left(F_{6,104}=2.14\right.$,

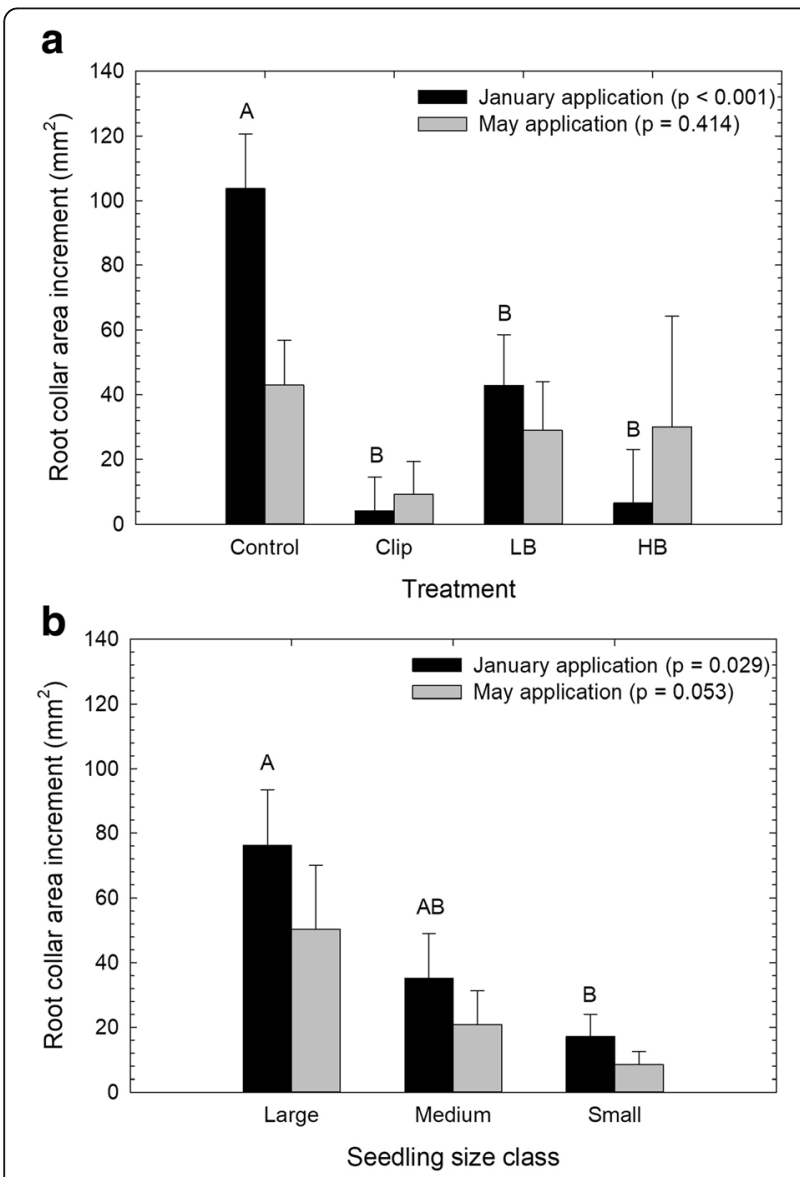

Fig. 6 Root collar area increment $\left(\mathrm{mm}^{2}\right)$ from pre treatment through August 2014 for the January and May applications by (a) study treatment and (b) longleaf pine seedling size class from South Carolina, USA. The same letter within an application month indicates no statistical difference from pair-wise comparisons
$P=0.060)$, and needle $\left(F_{6,105}=0.87, P=0.517\right)$ biomass for the January application. Total seedling biomass was greater for seedlings in the Control treatment than in Clip $\left(F_{1,105}=20.61, P<0.001\right)$ or HB $\left(F_{1,105}=7.24, P<\right.$ 0.041 ) treatments, and stem and root biomass were each greater for seedlings in the Control treatment than in the Clip treatment (stem $F_{1,105}=22.47, P<0.001$; root $F_{1,105}=22.77, P<0.001$; Fig. 7 a). Needle biomass did not differ among treatments. In the May application, we found no significant interaction effects between seedling size and treatment on total biomass $\left(F_{6,67}=1.13, P=\right.$ $0.355)$ or any of the biomass components (roots $F_{6,67}=$ 1.34, $P=0.252$; stem $F_{6,67}=0.97, P=0.450$; needles $F_{6,68}$ $=0.68, P=0.666)$. Of the component seedling biomass, only root biomass was different among treatments, with greater biomass for seedlings in the Control treatment than in the LB treatment $\left(F_{1,105}=9.06, P=0.019\right.$; Fig. $\left.7 \mathrm{~b}\right)$.

For each seedling, we plotted RCD and height from the final measurement period (Fig. 8). Using a threshold of $15 \mathrm{~cm}$ height as an indicator of grass stage emergence

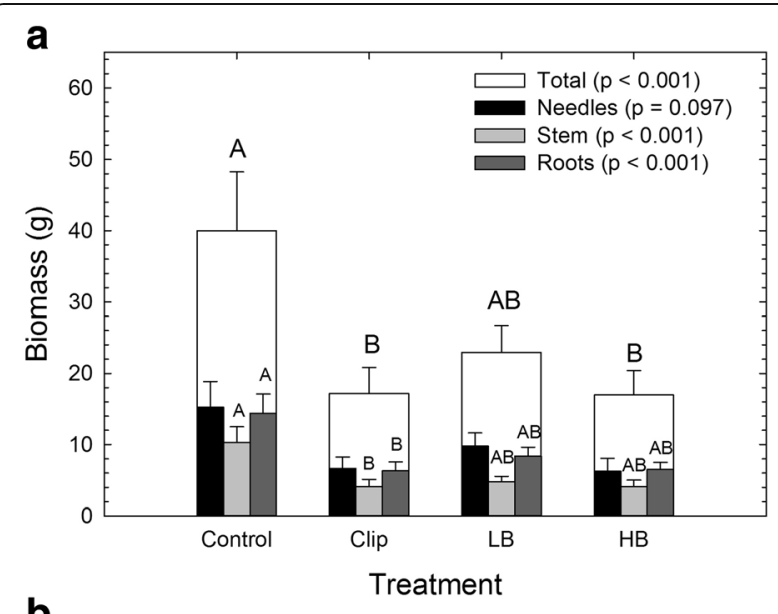

b

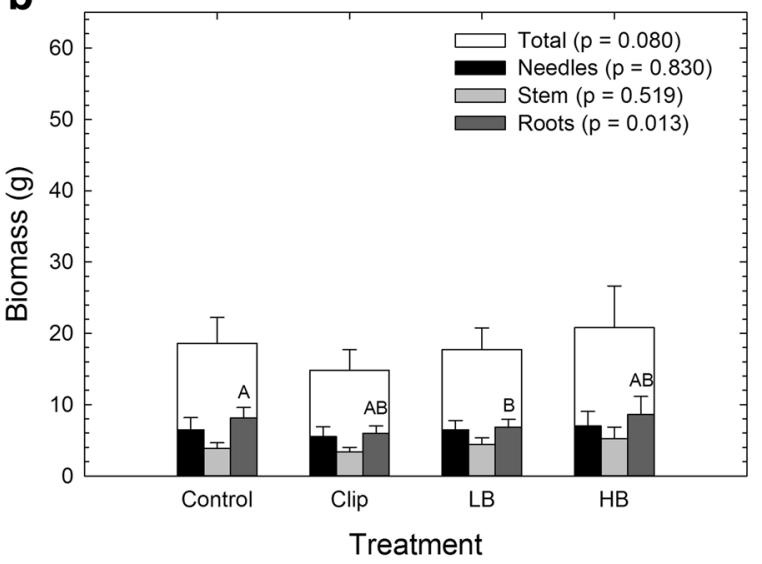

Fig. 7 Biomass of needles, stems, roots, and total seedlings from the (a) January application and (b) May application after destructive sampling of longleaf pine seedlings in South Carolina, USA, in August 2014 


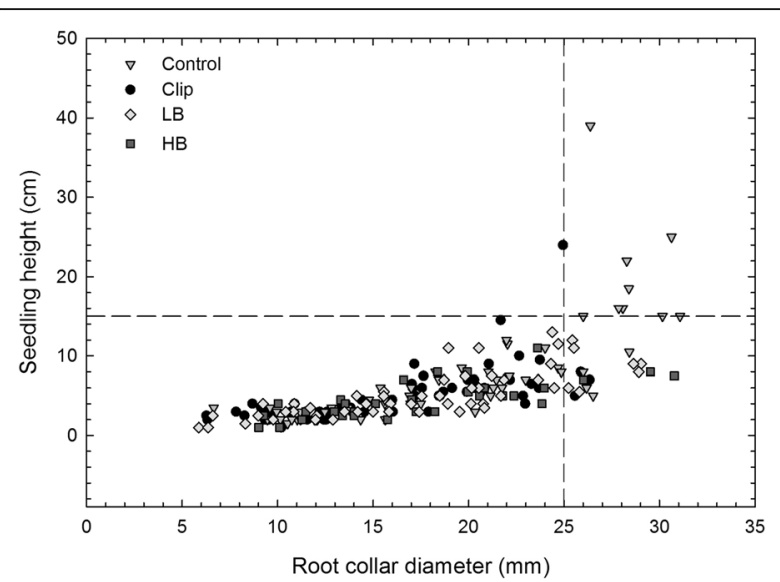

Fig. 8 Relationship between root collar diameter $(\mathrm{mm})$ and height $(\mathrm{cm})$ in August 2014 by treatment, for each longleaf pine seedling measured in South Carolina, USA. The horizontal dashed line at 15 $\mathrm{cm}$ height represents the threshold for height growth, and the vertical dashed line is at $25 \mathrm{~mm}$, which is the rule-of-thumb root collar diameter for emergence from the grass stage

(e.g., Nelson et al. 1985, Knapp et al. 2013), there were 10 seedlings that had emerged from the grass stage in August 2014, nine of which were from the Control treatment and one of which was from the Clip treatment. The nine seedlings from the Control treatment each had $\mathrm{RCD}>25 \mathrm{~mm}$.

\section{Discussion}

With historical fire return intervals reported to have been as frequent as 1 to 3 years (Frost 2006, Huffman 2006, Stambaugh et al. 2011), longleaf pine must be able to survive fire during the seedling stage for successful regeneration to occur. Similar to previous studies, our results provide evidence that longleaf pine seedlings are fire resistant but not fireproof, and that seedling size and fire intensity each affect seedling survival (Hypothesis 1). In a prescribed fire study of in situ longleaf pines that ranged in size from grass stage seedlings to saplings, Jack et al. (2010) found that grass stage seedlings (defined as $<0.2 \mathrm{~m}$ tall) had greater mortality than larger seedlings and saplings. Results from our study demonstrate that the size of seedlings within the grass stage also affects the probability of survival. Previous studies have reported a range of root collar diameter thresholds for fire resistance. Bruce (1951) reported that all grass stage seedlings with root collar diameters greater than $5.1 \mathrm{~mm}$ survived a winter burn in Mississippi, USA; Croker and Boyer (1975) cite $7.6 \mathrm{~mm}$ as the threshold for fire resistance; and Brockway et al. (2006) cited a threshold of $13.0 \mathrm{~mm}$. Generally, our results suggest that the probability of seedling survival one year after fire exceeds $50 \%$ for seedlings with root collar diameters greater than $15 \mathrm{~mm}$ for the high-temperature burn treatment. Our results indicate that the low-temperature burn treatment had little effect on seedling mortality. However, reduced survival of small seedlings after the second growing season, even in the low-temperature burn treatment, demonstrates the potential importance of the interaction between seedling size and fire intensity for grass stage seedling mortality.

The best models for seedling survival (of only burned seedlings) differed for survival near the end of the first (August 2013) and second (August 2014) growing seasons, although initial seedling size was included in both models. In addition to initial seedling size, the area under the time-temperature curve above $60{ }^{\circ} \mathrm{C}$ was an important predictor of seedling survival after the first growing season. Several publications have discussed the relevance of Area60, as a measure of heat dosage, to biotic response (Bova and Dickinson 2005, Kennard et al. 2005, Wally et al. 2006). The measure of maximum temperature, used to standardize treatment delivery in our study, may not as strongly indicate conditions experienced by plant tissues exposed to fire because both temperature and duration affect tissue damage (Bova and Dickinson 2008, Stephan et al. 2010). Strong et al. (2013) found that the area under the time-temperature curve was a better predictor of bunchgrass (Aristida purpurea Nutt.) mortality than maximum temperature or the duration above $60{ }^{\circ} \mathrm{C}$. In contrast, the best model for seedling survival after the second growing season in our study included maximum temperature rather than the area under the curve. Given the highly controlled treatment delivery in this study, correlations among fire intensity variables (Max, Area60, Dur60) were likely higher than what would be expected from a natural fire environment (Bova and Dickinson 2008). In addition, the thermocouples, having been placed immediately adjacent to the terminal bud during treatment delivery, provided an estimate of the fire environment of each seedling but did not measure actual tissue temperature.

The best model for seedling survival at the end of the second growing season, which encompassed both the direct, immediate mortality as well as delayed effects, included the month of treatment application. There was greater mortality within the second growing season across all size classes for both burn treatments in the May application, whereas mortality patterns for the January application were similar after the first and second growing season. We speculate that interactions among the fire treatment and environmental conditions may have contributed to our results. Although we achieved similar maximum temperatures with each burn application month, the area under the time-temperature curve and the duration above $60{ }^{\circ} \mathrm{C}$ were both greater in the May application than in the January application, perhaps due to higher air temperature during burn 
application in May. Moreover, the 2014 growing season was drier than average, and it is not known how interactions among environmental stress and fire affect mortality patterns in longleaf pine seedlings. Additional research is warranted to explore the mechanistic drivers of seasonal fire effects on longleaf pine seedling responses.

Sprouting is widely accepted as a persistence mechanism for hardwood trees (Bond and Midgley 2001, Del Tredici 2001) and is commonly discussed as an important fire adaptation for several pine species (e.g., shortleaf pine (Pinus echinata Mill.), pitch pine (P. rigida Mill.); Mattoon 1915, Welch et al. 2000). However, sprouting of longleaf pine seedlings has received relatively little attention. Farrar (1975) used mechanical clipping to test for sprouting responses and reported that up to $60 \%$ of small grass stage seedlings sprouted, with lower sprouting rates as tree size increased. We observed sprouting across all study treatments, including the control, but the rate of sprouting did not exceed $30 \%$ of the original population for any seedling size and treatment combination. However, sprouting was more common for small seedlings and seedlings in the high-temperature burn treatment, suggesting that the sprouting response was associated with severity of seedling damage. Although sprouting appears to contribute to the short-term fire resistance of longleaf pine seedlings, additional research is needed to determine if sprouting affects the vigor, development, or survival of longleaf pine seedlings through time.

Our results support the hypothesis that prescribed burning causes short-term reductions in seedling growth (Hypothesis 2), although responses depended on fire treatment and varied between the two application months. We did not quantify foliar consumption following the burns but observed that the high-temperature burn treatment completely consumed seedling foliage (Fig. 2c), while low-temperature burn treatment had more variable needle consumption. Regardless, all burned seedlings experienced either nearly complete needle consumption or scorch. These results suggest that short-term growth reductions of longleaf pine seedlings may be due to allocation of carbohydrates for needle production rather than to direct effects of heat damage. This is further supported by the lack of significant differences in needle biomass among treatments, as seedlings prioritized needle growth following consumption or removal.

Regardless of treatment, root collar area increment was low for seedlings treated with the May application, and the majority of root collar diameter growth of seedlings in the Control treatment of the January application occurred between January and May 2013 (data not shown). Low growth rates from May 2013 through the end of the study for seedlings in all treatments (including the Controls) in both treatment application months suggest that additional factors (external to study treatments) were limiting growth. For example, abnormally high rainfall in the 2013 growing season (e.g., Knapp et al. 2008) and abnormally low rainfall in the 2014 growing season (e.g., Rodríguez-Trejo et al. 2003) may have reduced the growth potential for all seedlings and contributed to the growth difference observed between the Control seedlings from the January and May application months. Assuming that external factors were limiting growth of all seedlings in this study, it is likely that growth reductions due to treatment effects may have been more pronounced in years with more favorable growing conditions.

Emergence from the grass stage is a critical event for longleaf pine seedling development. Previous studies reported that burning in May can stimulate height growth of longleaf pine seedlings, possibly due to control of competition or reduced infection of brown-spot needle blight (Maple 1977, Grelen 1978). We did not address effects of our experimental burning on the incidence of brown-spot needle blight by excluding infected seedlings from the sampling population. We removed understory competition adjacent to each seedling across all treatments in this study and found no evidence that burning further improved grass stage emergence. The size of the root system (often expressed by the surrogate measure of root collar diameter) tends to provide consistent indication of height growth emergence (Knapp et al. 2006). Although other studies have suggested that competition control may affect the relationship between seedling root collar diameter and height (Ramsey et al. 2003), our results support the rule of thumb that height growth begins when the root collar reaches approximately $25 \mathrm{~mm}$ diameter.

In contrast to our expectation, several of our results indicate that season of burn affected longleaf pine seedling response (Hypothesis 3). Although previous experimental studies have generally reported no effects of burn month or season on longleaf pine mortality across tree size classes (Glitzenstein et al. 1995, Jack et al. 2010), our study, which considers a smaller range of seedling sizes, suggests that season of burn may interact with seedling size and fire intensity to affect survival response. For example, mortality of Small seedlings was greater for the growing season application than the dormant season application for the low-temperature burn treatment, but the hightemperature burn treatment resulted in high mortality regardless of season. In contrast, Medium seedlings were large enough for high survival regardless of burn season for the low-temperature burn treatment but had lower survival with growing season burns than dormant season burns for the high-temperature burn treatment (Fig. 3). 
For Large seedlings, burn season had no effect regardless of fire intensity. Given that ambient temperatures were higher during burns in May than in January, and the fire intensity measures of Area60 and Dur60 were greater in May than in January, we cannot determine if the burn season effect would be attributed to seedling physiology or to differences in fire treatment intensity. However, the mortality models suggest that the effect of burn season on seedling mortality was primarily attributed to differences in mortality that took place during the second growing season.

The manipulative, experimental approach taken in this study provides unique insight into fire's effects on naturally regenerated, grass stage longleaf pine seedlings, yet comes with important trade-offs and limitations. For example, the thermocouples used in the study were positioned adjacent to the terminal bud of the target seedling but did not reflect the true temperature of the plant tissue. Thermocouples are commonly used to describe characteristics of fire behavior, and, while having been found to provide useful information, were limited to recording the temperature of the thermocouple device itself, as influenced by its materials and construction, rather than the energy output of the fire (Kennard et al. 2005, Bova and Dickinson 2008, Kremens et al. 2010). Although the treatments we applied were developed based on comparable data collected from actual prescribed burns (Fig. 1), the use of a PBST does not recreate all aspects of prescribed burning (Kral et al. 2015); for example, the delivery of heat from above with the PBST differs from fire movement with an operational prescribed burn, and we purposefully removed most surrounding fuels to better control the time-temperature curves. Thus, the study design includes a trade-off between experimental control and direct representation of operational conditions.

\section{Management implications}

In naturally regenerated longleaf pine forests and woodlands, seedlings and saplings are commonly observed in aggregations within canopy openings (Platt et al. 1988b, Pecot et al. 2007), which previous studies have attributed to competitive exclusion by canopy trees (Brockway and Outcalt 1998, Gagnon et al. 2004) and seedling mortality beneath the canopy due to greater fire intensities caused by needle accumulation (Grace and Platt 1995a, Avery et al. 2004). Our results suggest that these two factors likely work in combination to affect the spatial distribution of natural regeneration. Growth suppression of longleaf pine seedlings by canopy trees has been well documented (Boyer 1963, Croker and Boyer 1975, Grace and Platt 1995b), with little seedling growth occurring when basal area exceeds $9 \mathrm{~m}^{2} \mathrm{ha}^{-1}$ (Mitchell et al. 2006). Likewise, fire intensity has been reported to increase with proximity to longleaf pine canopy trees (Williamson and Black 1981). Our results demonstrate that seedlings across the size range observed in this study had relatively good survival with low-temperature burns, but survival was stratified by seedling size with greater fire intensity. Fire behavior is variable at fine scales within longleaf pine ecosystems (Hiers et al. 2009), suggesting that seedling survival may also be spatially variable. As indicated by our findings, the probability of survival would decrease beneath canopy trees, where seedling size is reduced by competition and fire intensity is likely greater due to needle accumulation.

Longleaf pine plantations are established as an initial step in ecosystem restoration where canopy longleaf pines no longer exist (Brockway et al. 2005) or to meet objectives related to wildlife, timber, or pine needle production (South 2006). In a restoration context, reintroducing fire is considered to be critical for maintaining ecosystem function over long timescales (Freeman and Jose 2009, Martin and Kirkman 2009, Addington et al. 2012). Results from this study indicate that the risk of mortality in longleaf pine plantations is relatively high for seedlings with root collars less than $15 \mathrm{~mm}$ diameter. High-quality container-grown longleaf pine seedlings are recommended to have root collar diameters of 7 to $9 \mathrm{~mm}$ before planting (Barnett and McGilvray 2000), although studies have reported root collar diameters of container-grown seedlings to range from 2.2 to $11.0 \mathrm{~mm}$ at planting (South et al. 2005). Growth rates of longleaf pine seedlings are variable but have been reported to range from 2 to over $10 \mathrm{~mm}$ per year without canopy competition (South et al. 2005, Hu et al. 2012a). Depending on size at planting and subsequent growth rates, longleaf pine seedlings may take several years to develop root collars greater than $15 \mathrm{~mm}$ diameter. Recently, underplanting has been suggested as a viable option for converting existing pine stands to longleaf pine (Kirkman et al. 2007, Hu et al. 2012b, Knapp et al. 2013). The retention of canopy trees has been reported to reduce growth rates of planted seedlings, which potentially extends the vulnerability of longleaf pine seedlings to fire mortality.

\section{Conclusion}

Although fire simulation methods are imperfect in mimicking prescribed burn conditions and effects, the controlled and repeatable application of burn treatments, as used in this study, cannot be achieved with prescribed burning. Our results demonstrate fire resistance of longleaf pine seedlings, but at the same time reveal that greater fire intensity selects against small longleaf pine seedlings. Moreover, fire season may impact survival of grass stage longleaf pine seedlings but further interacts with seedling size and fire intensity. Other factors that may affect 
seedling response to fire, such as seedling age and vigor, environmental conditions, or interactions with nearby plants, were not tested in this study; thus, additional research is needed to determine mechanisms for seedling responses. Understanding the effects of fire on grass stage longleaf pine seedlings can inform burn prescriptions to ensure that natural or artificial regeneration needs are met while maintaining a frequent-fire regime for ecosystem management.

\section{Abbreviations}

ANOVA: analysis of variance; Area60: the area under the thermocouple temperature curve above a threshold of $60^{\circ} \mathrm{C}$; DBH: diameter at breast height; Dur60: the duration (number of seconds) thermocouple temperature remained above a threshold of $60^{\circ} \mathrm{C} ; \mathrm{HB}$ : a high-temperature burn treatment; LB: a low-temperature burn treatment; Max: maximum thermocouple temperature; PBST: prescribed burn simulation tool; RCD: root collar diameter; TC: thermocouple

\section{Acknowledgements}

We thank H. Hu, A. Bhuta, H. Hadwin, and S. Broom for their assistance with data collection, and the staff of Brosnan Forest, including J. Smith and J. Raglin, for logistical support. The burn tool used in this study (PBST) was designed by B.P. van Eerden for research on fire effects on reproductive biology of wiregrass (Aristida stricta Michaux). We thank P. Curtin for comments on an early version of this manuscript.

\section{Funding}

The paper is Technical Contribution No. 6650 of the Clemson University Experiment Station, which is based upon work supported by NIFA/USDA, under project number SC-1700526.

\section{Availability of data and materials}

The datasets used or analyzed during the current study are available from the corresponding author on reasonable request.

\section{Authors' contributions}

B.O. Knapp had major contribution to study conception and design, data collection, data analyses, and writing the manuscript, as well as minor contribution to securing funding support. L.S. Pile had major contribution to study conception and design, data collection, and writing the manuscript, as well as minor contribution to data analyses. J.L. Walker had major contribution to study conception and design and writing the manuscript, as well as minor contribution to data analyses. G.G. Wang had major contribution to study conception and design, securing funding support, and writing the manuscript, as well as minor contribution to data analyses. All authors read and approved the final manuscript.

\section{Ethics approval and consent to participate}

Not applicable.

\section{Consent for publication}

Not applicable.

\section{Competing interests}

The authors declare that they have no competing interests.

\section{Publisher's Note}

Springer Nature remains neutral with regard to jurisdictional claims in published maps and institutional affiliations.

\section{Author details}

${ }^{1}$ School of Natural Resources, University of Missouri, 203-S Anheuser-Busch Natural Resources Building, Columbia, Missouri 62511, USA. ${ }^{2}$ Department of Forestry and Environmental Conservation, Clemson University, 261 Lehotsky Hall, Clemson, South Carolina 29634, USA. ${ }^{3}$ US Department of Agriculture, Forest Service, Southern Research Station, Clemson University, 233 Lehotsky Hall, Clemson, South Carolina 29634, USA. ${ }^{4}$ Present affiliation: US Department of Agriculture, Forest Service, Northern Research Station, 202 Anheuser-Busch Natural Resources Building, Columbia, Missouri 65211, USA.

Received: 20 June 2018 Accepted: 3 July 2018

Published online: 30 August 2018

\section{References}

Addington RN, Greene TA, Elmore ML, Prior CE, Harrison WC (2012) Influence of herbicide site preparation on longleaf pine ecosystem development and fire management. Journal of Applied Forestry 36(4):173-180 https://doi.org/10. 5849/sjaf.11-012

Addington RN, Knapp BO, Sorrell GG, Elmore ML, Wang GG, Walker JL (2015) Factors affecting broadleaf woody vegetation in upland pine forests managed for longleaf pine restoration. Forest Ecology and Management 354: 130-138.

Attiwill PM (1994) The disturbance of forest ecosystems: the ecological basis for conservative management. Forest Ecology and Management 63(2-3): 247-300.

Avery CR, Cohen S, Parker KC, Kush JS (2004) Spatial patterns of longleaf pine (Pinus palustris) seedling establishment on the Croatan National Forest, North Carolina. Journal of the North Carolina Academy of Science 120(4):131-142.

Barnett JP, McGilvray JM (2000) Growing longleaf pine seedlings in containers. Native Plants Journal 1(1):54-58 https://doi.org/10.3368/npj.1.1.54.

Bond WJ, Midgley JJ (2001) Ecology of sprouting in woody plants: the persistence niche. Trends in Ecology \& Evolution 16(1):45-51 https://doi.org/ 10.1016/50169-5347(00)02033-4.

Bova AS, Dickinson MB (2005) Linking surface-fire behavior, stem heating, and tissue necrosis. Canadian Journal of Forest Research 35(4):814-822 https:// doi.org/10.1139/×05-004.

Bova AS, Dickinson MB (2008) Beyond "fire temperatures": calibrating thermocouple probes and modeling their response to surface fires in hardwood fuels. Canadian Journal of Forest Research 38(5):1008-1020 https://doi.org/10.1139/X07-204

Boyer, W.D. 1963. Development of longleaf pine seedlings under parent trees. USDA Forest Service Research Paper RP-SO-4, Southern Forest Experiment Station, New Orleans, Louisiana, USA.

Boyer WD (1987) Volume growth loss: a hidden cost of periodic prescribed burning in longleaf pine? Southern Journal of Applied Forestry 11(3):154-157.

Boyer, W.D. 1990. Pinus palustris, Mill. Longleaf pine. Pages 405-412 in: R.M. Burns and B.H. Honkala, editors. Silvics of North America. Volume 1. Conifers. USDA Forest Service Agricultural Handbook 654, Washington, D.C., USA.

Brockway DG, Lewis CE (1997) Long-term effects of dormant-season prescribed fire on plant community diversity, structure and productivity in a longleaf pine wiregrass ecosystem. Forest Ecology and Management 96(1-2):167-183.

Brockway DG, Outcalt KW (1998) Gap-phase regeneration in longleaf pine wiregrass ecosystems. Forest Ecology and Management 106(2-3):125-139.

Brockway, D.G., K.W. Outcalt, and W.D. Boyer. 2006. Longleaf pine regeneration ecology and methods. Pages 95-133 in: S. Jose, E.J. Jokela, and D.L. Miller, editors. The longleaf pine ecosystem: ecology, silviculture, and restoration. Springer Science+Business Media, LLC, New York, New York, USA.https://doi. org/10.1007/978-0-387-30687-2_4.

Brockway, D.G., K.W. Outcalt, D.J. Tomczak, and E.E. Johnson 2005. Restoration of longleaf pine ecosystems. USDA Forest Service General Technical Report SRSGTR-83, Southern Research Station, Asheville, North Carolina, USA.

Brose PH, Van Lear DH, Keyser PD (1999) A shelterwood-burn technique for regenerating productive upland oak sites in the Piedmont region. Southern Journal of Applied Forestry 23(3):158-163.

Bruce D (1951) Fire resistance of longleaf pine seedlings. Journal of Forestry 49: $739-740$.

Burnham KP, Anderson DR (2003) Model selection and mulitmodel inference: a practical information-theoretic approach. Springer Science+Business Media. In: LLC. USA, New York, New York.

Croker TC, Boyer WD (1975) Regenerating longleaf pine naturally. USDA Forest Service Research Paper RP-SO-105, Southern Forest Experiment Station. In: New Orleans. Louisiana, USA.

Del Tredici P (2001) Sprouting in temperate trees: a morphological and ecological review. The Botanical Review 67(2):121-140 https://doi.org/10. 1007/BF02858075.

Drewa PB, Platt WJ, Moser EB (2002) Fire effects on resprouting of shrubs in headwaters of Southeastern longleaf pine savannas. Ecology 83(3):755-767 https://www.jstor.org/stable/3071879. 
Ellair DP, Platt WJ (2013) Fuel composition influences fire characteristics and understorey hardwoods in pine savanna. Journal of Ecology 101(1):192-201 https://doi.org/10.1111/1365-2745.12008.

Farrar RM (1975) Notes: sprouting ability of longleaf pine. Forest Science 21(2):189-190.

Franklin JF, Spies TA, Van Pelt R, Carey AB, Thornburgh DA, Berg DR, Lindenmayer DB, Harmon ME, Keeton WS, Shaw DC, Bible K, Chen J (2002) Disturbances and structural development of natural forest ecosystems with silvicultural implications, using Douglas-fir forests as an example. Forest Ecology and Management 155(1-3):399-423.

Freeman JE, Jose S (2009) The role of herbicide in savanna restoration: effects of shrub reduction treatments on the understory and overstory of a longleaf pine flatwoods. Forest Ecology and Management 257(3):978-986 https://doi. org/10.1016/j.foreco.2008.10.041.

Frost, C 2006. History and future of the longleaf pine ecosystem. Pages 9-42 in: S. Jose, E.J. Jokela, and D.L. Miller, editors. The longleaf pine ecosystem: ecology, silviculture, and restoration. Springer Science+Business Media, LLC, New York, New York, USA. https://doi.org/10.1007/978-0-387-30687-2_2.

Gagnon JL, Jokela EJ, Moser WK, Huber DA (2004) Characteristics of gaps and natural regeneration in mature longleaf pine flatwoods ecosystems. Forest Ecology and Management 187(2-3):373-380.

Gibson DJ, Hartnett DC, Merrill GLS (1990) Fire temperature heterogeneity in contrasting fire prone habitats: Kansas tallgrass prairie and Florida sandhill. Bulletin of the Torrey Botany Club 117(4):349-356 https://doi.org/10.2307/ 2996832.

Glitzenstein JS, Platt WJ, Streng DR (1995) Effects of fire regime and habitat on tree dynamics in north Florida longleaf pine savannas. Ecological Monographs 65(4):441-476 https://doi.org/10.2307/2963498.

Grace SL, Platt WJ (1995a) Effects of adult tree density and fire on the demography of pregrass stage juvenile longleaf pine (Pinus palustris Mill.). Journal of Ecology 83(1):75-86 https://doi.org/10.2307/2261152.

Grace SL, Platt WJ (1995b) Neighborhood effects on juveniles in an old-growth stand of longleaf pine, Pinus palustris. Oikos 72(1):99-105 https://doi.org/10. 2307/3546043.

Grelen, H.E 1978. May burns stimulate growth of longleaf pine seedlings. USDA Forest Service Research Note RN-SO-234, Southern Forest Experiment Station, New Orleans, Louisiana, USA.

Hiers JK, O'Brien JJ, Mitchell RJ, Grego JM, Loudermilk EL (2009) The wildland fuel cell concept: an approach to characterize fine-scale variation in fuels and fire in frequently burned longleaf pine forests. International Journal of Wildland Fire 18(3):315-325 https://doi.org/10.1071/WF08084.

Hiers JK, O'Brien JJ, Will RE, Mitchell RJ (2007) Forest floor depth mediates understory vigor in xeric Pinus palustris ecosystems. Ecological Applications 17(3):806-814 https://doi.org/10.1890/06-1015.

Hiers JK, Wyatt R, Mitchell RJ (2000) The effects of fire regime on legume reproduction in longleaf pine savannas: is a season selective? Oecologia 125(4):521-530.

Hu H, Wang GG, Walker JL, Knapp BO (2012a) Silvicultural treatments for converting loblolly pine to longleaf pine dominance: effects on resource availability and their relationships with planted longleaf pine seedlings. Forest Ecology and Management 282:115-123.

Hu H, Wang GG, Walker JL, Knapp BO (2012b) Silvicultural treatments for converting loblolly pine to longleaf pine dominance: effects on planted longleaf pine seedlings. Forest Ecology and Management 276:209-216.

Huffman JM (2006) Historical fire regimes in Southeastern pine savannas. In: Dissertation. Louisiana State University, Baton Rouge, Louisiana, USA.

Jack, S.B., J.K. Kiers, R.J. Mitchell, and J.L. Gagnon. 2010. Fuel loading and fire intensity: effects on longleaf pine seedling survival. USDA Forest Service General Technical Report GTR-SRS-121, Southern Research Station, Asheville, North Carolina, USA.

Keeley JE (2012) Ecology and evolution of pine life histories. Annals of Forest Science 69(4):445-453 https://doi.org/10.1007/s13595-012-0201-8.

Kennard DK, Outcalt KW, Jones D, O'Brien JJ (2005) Comparing techniques for estimating flame temperature of prescribed fires. Fire Ecology 1(1):75-84 https://doi.org/10.4996/fireecology.0101075.

Kirkman LK, Mitchell RJ, Kaeser MJ, Pecot SD, Coffey KL (2007) The perpetual forest: using undesirable species to bridge restoration. Journal of Applied Ecology 44(3):604-614 https://doi.org/10.1111/j.1365-2664.2007.01310.x.

Knapp BO, Wang GG, Walker JL (2008) Relating the survival and growth of planted longleaf pine seedlings to microsite conditions altered by site preparation treatments. Forest Ecology and Management 255(11):3768-3777 https://doi.org/10.1016/j.foreco.2008.03.013.
Knapp BO, Wang GG, Walker JL (2013) Effects of canopy structure and cultural treatments on the survival and growth of Pinus palustris Mill. seedlings underplanted in Pinus taeda L. stands. Ecological Engineering 57:46-56 https://doi.org/10.1016/j.ecoleng.2013.04.014.

Knapp BO, Wang GG, Walker JL, Cohen S (2006) Effects of site preparation treatments on early growth and survival of planted longleaf pine (Pinus palustris Mill.) seedlings in North Carolina. Forest Ecology and Management 226(1-3):122-128.

Koskela J (2000) A process-based growth model for the grass stage pine seedlings. Silva Fennica 34(1):3-20 https://doi.org/10.14214/sf.640.

Kral KC, Limb RF, Hovick TJ, McGranahan DA, Field AL, O'Brien PL (2015) Simulating grassland prescribed fires using experimental approaches. Fire Ecology 11(3):34-44 https://doi.org/10.4996/fireecology.1103034.

Kremens RL, Smith AMS, Dickinson MB (2010) Fire metrology: current and future directions in physics-based measurements. Fire Ecology 6(1):13-35 https:// doi.org/10.4996/fireecology.0601013.

Maple, W.R 1977. Spring burns aid longleaf pine seedling height growth. USDA Forest Service Research Note RN-SO-228, Southern Forest Experiment Station, New Orleans, Louisiana, USA.

Martin KL, Kirkman KL (2009) Management of ecological thresholds to reestablish disturbance-maintained herbaceous wetlands of the south-eastern USA. Journal of Applied Ecology 46(4):906-914 https://doi.org/10.1111/j.13652664.2009.01659.x.

Mattoon, W.R. 1915. Life history of shortleaf pine. USDA Bulletin No. 244, Washington, D.C., USA. https://doi.org/10.5962/bhl.title.108486.

Mitchell RJ, Hiers JK, O'Brien J, Starr G (2009) Ecological forestry in the Southeast: understanding the ecology of fuels. Journal of Forestry 107(8):391-397.

Mitchell RJ, Hiers JK, O'Brien JJ, Jack SB, Engstrom RT (2006) Silviculture that sustains: the nexus between silviculture, frequent prescribed fire, and conservation of biodiversity in longleaf pine forests of the southeastern United States. Canadian Journal of Forest Research 36(11):2724-2736 https:// doi.org/10.1139/x06-100.

Moule B (2013) Comparing mechanical mastication, herbicide application, and prescribed fire within an established longleaf pine (Pinus palustris Mill.) ecosystem, Dissertation. Clemson University, Clemson, South Carolina, USA.

Nelson LR, Zutter BR, Gjerstad DH (1985) Planted longleaf pine seedlings respond to herbaceous weed control using herbicides. Southern Journal of Applied Forestry 9(4):236-240.

O'Brien JJ, Hiers JK, Callaham MAJ, Mitchell RJ, Jack SB (2008) Interactions among overstory structure, seedling life-history traits, and fire in frequently burned neotropical pine forests. Ambio 37(7):542-547 https://doi.org/10.1579/00447447-37.7.542.

Olson MS, Platt WJ (1995) Effects of habitat and growing season fires on resprouting of shrubs in longleaf pine savannas. Vegetatio 119(2):101-118 https://doi.org/10.1007/BF00045593.

Palik BJ, Mitchell RJ, Hiers JK (2002) Modeling silviculture after natural disturbance to sustain biodiversity in the longleaf pine (Pinus palustris) ecosystem: balancing complexity and implementation. Forest Ecology and Management 155(1-3):347-356.

Pecot SD, Mitchell RJ, Palik BJ, Moser EB, Hiers JK (2007) Competitive responses of seedlings and understory plants in longleaf pine woodlands: separating canopy influences above and below ground. Canadian Journal of Forest Research 37(3):634-648 https://doi.org/10.1139/X06-247.

Platt WJ, Evans GW, Davis MM (1988a) Effects of fire season on flowering of forbs and shrubs in longleaf pine forests. Oecologia 76(3):353-363 https://doi.org/ 10.1007/BF00377029.

Platt WJ, Evans GW, Rathbun SL (1988b) The population dynamics of a long-lived conifer (Pinus palustris). The American Naturalist 131(4):491-525 https://doi. org/10.1086/284803.

Ramsey CL, Jose S, Brecke BJ, Merritt S (2003) Growth response of longleaf pine (Pinus palustris Mill.) seedlings to fertilization and herbaceous weed control in an old field in southern USA. Forest Ecology and Management 172(2-3):281-289.

Rodríguez-Trejo DA, Duryea ML, White TL, English JR, McGuire J (2003) Artificially regenerating longleaf pine in canopy gaps: initial survival and growth during a year of drought. Forest Ecology and Management 180(1-3):25-36.

Schafer JL, Breslow BP, Hohmann MG, Hoffmann WA (2015) Relative bark thickness is correlated with tree species distributions along a fire frequency gradient. Fire Ecology 11(1):74-87 https://doi.org/10.4996/fireecology. 1101074.

South DB (2006) Planting longleaf pine at wide spacings. Native Plants Journal 7(1):79-88 https://doi.org/10.2979/NPJ.2006.7.1.79. 
South DB, Harris SW, Barnett JP, Hainds MJ, Gjerstad DH (2005) Effect of container type and seedling size on survival and early height growth of Pinus palustris seedlings in Alabama, USA. Forest Ecology and Management 204(2-3): 385-398.

Stambaugh MC, Guyette RP, Marschall JM (2011) Longleaf pine (Pinus palustris Mill.) fire scars reveal new details of a frequent fire regime. Journal of Vegetation Science 22(6):1094-1104 https://doi.org/10.1111/j.1654-1103.2011. 01322.x.

Stephan K, Miller M, Dickinson MB (2010) First-order fire effects on herbs and shrubs: present knowledge and process modeling needs. Fire Ecology 6(1): 95-114 https://doi.org/10.4996/fireecology.0601095.

Streng DR, Glitzenstein JS, Platt WJ (1993) Evaluating effects of season of burn in longleaf pine forests: a critical literature review and some results from an ongoing long-term study. Proceedings of a Tall Timbers Fire Ecology Conference 18:227-263.

Strong DJ, Ganguli AC, Vermeire LT (2013) Fire effects on basal area, tiller production, and mortality of the $\mathrm{C}_{4}$ bunchgrass, purple threeawn. Fire Ecology 9(3):89-99 https://doi.org/10.4996/fireecology.0903089.

Thaxton JM, Platt WJ (2006) Small-scale fuel variation alters fire intensity and shrub abundance in a pine savanna. Ecology 87(5):1331-1337 https://www. ncbi.nlm.nih.gov/pubmed/16761611.

Van Lear DH, Carroll WD, Kapeluck PR, Johnson R (2005) History and restoration of the longleaf pine - grassland ecosystem: implications for species at risk. Forest Ecology and Management 211(1-2):150-165.

Veldman JW, Brudvig LA, Damschen El, Orrock JL, Mattingly WB, Walker JL (2014) Fire frequency, agricultural history and the multivariate control of pine savanna understorey plant diversity. Journal of Vegetation Science 25:14381449 https://doi.org/10.1111/jvs.12195.

Wahlenberg, W.G 1946. Longleaf pine: its use, ecology, regeneration, protection, growth, and management. Charles Lathrop Pack Forestry Foundation in cooperation with the USDA Forest Service, Washington, D.C., USA.

Waldrop TA, White DL, Jones SM (1992) Fire regimes for pine-grassland communities in the southeastern United States. Forest Ecology and Management 47(1-4):195-210..

Wally AL, Menges ES, Weekley CW (2006) Comparison of three devices for estimating fire temperatures in ecological studies. Applied Vegetation Science 9(1):97-108 https://doi.org/10.1111/j.1654-109X.2006.tb00659.x.

Welch NT, Waldrop TA, Buckner ER (2000) Response of southern Appalachian Table Mountain pine (Pinus pungens) and pitch pine (Pinus rigida) stands to prescribed burning. Forest Ecology and Management 136(1-3):185-197..

Wenk ES, Wang GG, Walker JL (2011) Within-stand variation in understorey vegetation affects fire behaviour in longleaf pine xeric sandhills. International Journal of Wildland Fire 20(7):866-875 https://doi.org/10.1071/WF10087..

Williamson GB, Black EM (1981) High temperature of forest fires under pines as a selective advantage over oaks. Nature 293:643-644 https://doi.org/10.1038/ 293643a0..

\section{Submit your manuscript to a SpringerOpen ${ }^{\circ}$ journal and benefit from:}

- Convenient online submission

- Rigorous peer review

- Open access: articles freely available online

- High visibility within the field

- Retaining the copyright to your article

Submit your next manuscript at $\boldsymbol{\nabla}$ springeropen.com 